Review Article

\title{
Epidemiology of Microsatellite Instability High (MSI-H) and Deficient Mismatch Repair (dMMR) in Solid Tumors: A Structured Literature Review
}

\author{
Maria Lorenzi $\mathbb{D}^{1},{ }^{1}$ Mayur Amonkar, ${ }^{2}$ Jacky Zhang, ${ }^{1}$ Shivani Mehta, ${ }^{1}$ and Kai-Li Liaw ${ }^{2}$ \\ ${ }^{1}$ Precision Xtract, Oakland, CA, USA \\ ${ }^{2}$ Merck \& Co, Inc., North Wales, PA, USA
}

Correspondence should be addressed to Maria Lorenzi; maria.lorenzi@precisionxtract.com

Received 9 October 2019; Revised 23 January 2020; Accepted 28 January 2020; Published 9 March 2020

Academic Editor: Giandomenico Roviello

Copyright (C) 2020 Maria Lorenzi et al. This is an open access article distributed under the Creative Commons Attribution License, which permits unrestricted use, distribution, and reproduction in any medium, provided the original work is properly cited.

Background. Given limited data on the epidemiology of MSI-H and dMMR across solid tumors (except colorectal cancer (CRC)), the current study was designed to estimate their prevalence. Materials and Methods. A structured literature review identified English language publications that used immunohistochemistry (IHC) or polymerase chain replication (PCR) techniques. Publications were selected for all tumors except CRC using MEDLINE, EMBASE, and Cochrane databases and key congresses; $\mathrm{CRC}$ and pan-tumor genomic publications were selected through a targeted review. Meta-analysis was performed to estimate pooled prevalence of MSI-H/dMMR across all solid tumors and for selected tumor types. Where possible, prevalence within tumor types was estimated by disease stages. Results. Of 1,176 citations retrieved, 103 and 48 publications reported prevalence of MSI-H and dMMR, respectively. Five pan-tumor genomic studies supplemented the evidence base. Tumor types with at least 5 publications included gastric $(n=39)$, ovarian $(n=23)$, colorectal $(n=20)$, endometrial $(n=53)$, esophageal $(n=6)$, and renal cancer $(n=8)$. Overall MSI-H prevalence (with 95\% CI) across 25 tumors was based on 90 papers $(28,213$ patients) and estimated at $14 \%(10 \%-19 \%)$. MSI-H prevalence among Stage $1 / 2$ cancers was estimated at 15\% (8\%-23\%); Stages 3 and 4 prevalence was estimated at $9 \%(3 \%-17 \%)$ and 3\% (1\%-7\%), respectively. Overall, dMMR prevalence across 13 tumor types (based on 54 papers and 20,383 patients) was estimated at $16 \%(11 \%-22 \%)$. Endometrial cancer had the highest pooled MSI-H and dMMR prevalence ( $26 \%$ and $25 \%$ all stages, respectively). Conclusions. This is the first comprehensive attempt to report pooled prevalence estimates of MSI-H/dMMR across solid tumors based on published data. Prevalence determined by IHC and PCR was generally comparable, with some variations by cancer type. Late-stage prevalence was lower than that in earlier stages.

\section{Introduction}

DNA mismatch repair (MMR) is a process that plays a key role in maintaining genomic stability by recognizing and repairing base-base mismatches and insertion/deletion of DNA generated during replication and recombination. Defects in MMR are associated with genome-wide instability and the progressive accumulation of mutations, especially regions of simple repetitive DNA sequences known as microsatellites, resulting in MSI. MSI-high (MSI-H) is a hypermutable phenotype that allows mutations to be accumulated rapidly, resulting in tumor development via the selection of cancer-promoting mutations in pathways that are responsible for maintaining functional DNA repair, apoptosis, and cell growth.

To test for MSI-H and dMMR statuses in solid tumors, polymerase chain reaction (PCR) and immunohistochemistry (IHC) methods have been widely accepted as respective testing platforms for these biomarkers. The PCR method uses a panel of microsatellite markers to detect size shifts in different loci. The IHC method uses a more direct test to determine the presence of MMR proteins. A tumor is typically classified as MSI-H if shifts are detected in at least 2 of 5 loci using the PCR method and dMMR if at least one MMR protein is absent using the IHC method. The use of NCI (BAT-25, BAT-26, D2S123, D5S346, and D17S250) [1] 
and Promega (BAT-25, BAT-26, NR-21, NR-24, and MONO-27) [2] panels in PCR and the use of MLH1, MSH2, MSH6, and PMS2 proteins in IHC are considered the gold standard approaches $[3,4,5]$.

Among patients diagnosed with metastatic cancer and MSI-H or dMMR, prognosis is generally poor [6]. Recently, evidence has mounted on the benefits of immunotherapy, especially with checkpoint inhibitors such as pembrolizumab on MSI-H/dMMR tumors $[7,8,9]$. Historically, most patients with a solid tumor diagnosis were not tested for MSI; a better understanding of MSI-H and dMMR prevalence can help estimate the size of the potential target population. To provide reliable estimates of MSI-H and dMMR prevalence, a comprehensive structured literature review was conducted to gather relevant and recent evidence on the epidemiology of MSI-H and dMMR across multiple tumors. When sufficient data were available, meta-analysis was performed to estimate the prevalence of MSI-H and dMMR tumors overall, across individual tumor types, and by stage of disease.

\section{Methods}

Study eligibility criteria outlined in Table 1 guided study identification and selection for the literature review.

2.1. Literature Review. Relevant studies were identified by searching the following through the Ovid platform: Medical Literature Analysis and Retrieval System Online (MEDLINE), Excerpta Medica database (Embase), and Cochrane Central Register of Controlled Trials. Predefined search strategies were executed on October $26^{\text {th }}, 2017$. Study design filters recommended by the Scottish Intercollegiate Guidelines Network (SIGN) were used. Population terms were adapted from published research [9]; no intervention or comparator terms were used.

Systematic reviews, meta-analyses, and key narrative reviews of interest were identified via hand searching. Targeted hand searches were conducted to identify colorectal cancer (CRC) studies and pan-tumor genomic studies reporting MSI-H/dMMR prevalence. Studies for all solid tumors except CRC were selected through database searches; CRC and pan-tumor genomic studies were selected through a targeted review. One reviewer reviewed all abstracts and proceedings identified through database searches and the targeted review according to the selection criteria. Studies identified as potentially eligible during abstract screening were screened in full-text by the same reviewer. The full-text studies identified at this stage were included for data extraction. The process of study identification and selection are summarized with Preferred Reporting Items for Systematic Reviews and Meta-Analyses (PRISMA) flow diagrams [10].

One reviewer extracted data on study characteristics, interventions, patient characteristics, and outcomes from included studies. The second reviewer independently extracted data from a random $10 \%$ of the publications, reconciled the data, and determined the error rate and missing data rate of data extraction by the first reviewer. The error rate (number of cells with incorrect data/number of cells with text) was $2.9 \%$, and the missing data rate (number of cells with missing data/number of blank cells) was $1.2 \%$ (an error rate greater than 5\% would have triggered extraction of a further $10 \%$ of publications by the second reviewer). All errors discovered through this process were corrected. Potential publication biases were checked through funnel plots. Data were stored and managed in a Microsoft Excel workbook.

Only studies that used PCR or IHC methods were included in this review. To increase validity of the metaanalysis, only studies that used NCI (BAT-25, BAT-26, D2S123, D5S346, and D17S250) or Promega (BAT-25, BAT-26, NR-21, NR-24, and MONO-27) panels in PCR and MLH1, MSH2, MSH6, and PMS2 proteins in IHC were included in the meta-analysis. The only exceptions were pan-tumor genomic studies, which used large-scale sequencing techniques to test for the presence of only the MLH1 gene. These genomic studies were included in sensitivity analyses to detect their potential effect on the meta-analysis.

Prevalence of MSI-H and/or dMMR was extracted overall, by tumor type, histology, stage, and country.

2.2. Meta-Analysis. Reported proportions were transformed according to the Freeman-Tukey variant of the arcsine square root (double arcsine) transformed proportion [11]. The pooled proportion was calculated by back-transforming the weighted mean of the transformed proportions, using the DerSimonian-Laird random effects model [12].

Meta-analysis was conducted using the metafor package version 1.9-9 in R 3.4.0. Weighting of each tumor type was based on cancer-specific prevalence estimates provided by the GLOBOCAN 2012 database from the World Health Organization [13]. For rare tumor types, when data were unavailable on the GLOBOCAN database, other databases and peer-reviewed publications were referenced [14-18]. Each tumor type was assigned a weight based on its general prevalence; in cases where two or more studies were included for a given tumor type, weight was split proportionally between studies based on the sample size.

\section{Results}

The study selection process for identification of studies reporting MSI-H or dMMR prevalence in the structured literature review is outlined in Figure 1. Overall, 1,176 publications were assessed for eligibility; a total of 156 fulltext publications were included based on the structured and targeted literature review.

3.1. Feasibility Assessment of Meta-Analysis. References for included studies can be found in Tables 2-4. Of the 156 included full-text publications, 103 studies reported prevalence of any MSI status, which included MSI-H, MSI-L (microsatellite instability-low), and MSS (microsatellite stable). Forty-eight studies reported prevalence of dMMR 
TABLE 1: Eligibility criteria.

\begin{tabular}{lc}
\hline Criteria & Description \\
\hline Population & Patients with solid tumors \\
\hline & (i) Assessment of prevalence of MSI-H (using NCI marker panel: BAT25, BAT26, D2S123, D5S346, and D17S250) or \\
& Promega marker panel: BAT25, BAT26, NR21, NR24, and MONO27) and/or dMMR (by immunohistochemistry for all four \\
& MMR proteins: MLH1, MSH2, MSH6, and PMS2) overall, by tumor type, by histology subtype, by stage, by treatment, by \\
& region, by country, and by gender
\end{tabular}

(a) Proportion of MSI as defined in study (e.g., MSI-H, MSI-L, and MSI-S)

Outcomes

(b) Proportion of dMMR and pMMR as defined in study

(ii) Survival rates by MSI-H/dMMR status overall, by stage and by tumor type

(a) Overall survival (OS) and progression-free survival (PFS)

(1) Hazard ratios along with 95\% confidence interval (CI)

(2) Median (in months) and 95\% CI

(iii) Objective response rate (ORR), defined as complete response (CR) or partial response (PR)

(iv) Disease control rate, defined as CR, PR, or stable disease

(i) Prospective and retrospective cohort studies

Study design

(ii) Randomized controlled trials

(iii) Case-control studies

(iv) Cross-sectional studies

(v) Controlled and uncontrolled longitudinal studies (cohorts or case series)

Language Only studies published in English will be included

Time No time limit

Abbreviations: dMMR, deficient mismatch repair; MLH1, MutL homolog 1; MSH2, MutS protein homolog 2; MSH6, MutS homolog 6; MSI-H, microsatellite instability high; MSI-L, microsatellite instability low; MSI-S/MSS, microsatellite stable; NCI, National Cancer Institute; pMMR, proficient mismatch repair; PMS2, postmeiotic segregation increased 2.

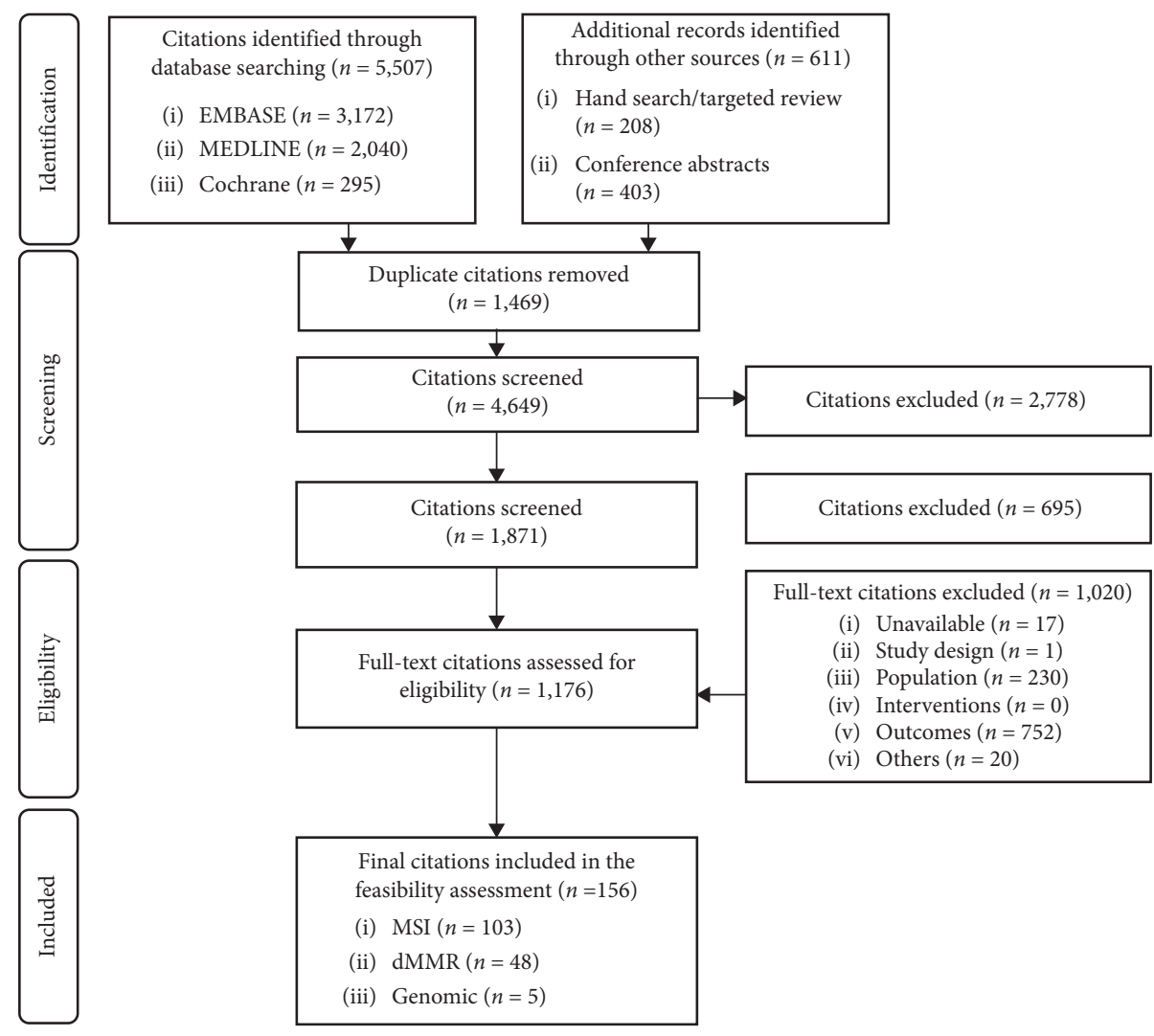

FIGURE 1: PRISMA study flow diagram of included studies for the structured literature review.

according to the eligibility criteria. Five large pan-tumor genomic studies reported MSI-H status across multiple solid tumors.
3.2. Study Characteristics. The most common tumor types (excluding CRC) identified were endometrial (53 studies), gastric (39 studies), ovarian (23 studies), renal (9 studies), 
TABle 2: References-MSI studies.

\begin{tabular}{|c|c|c|c|c|}
\hline Author & Year & Title & Journal & Tumor type \\
\hline Abraham & 2002 & $\begin{array}{l}\text { Microsatellite instability in intraductal } \\
\text { papillary neoplasms of the biliary tract }\end{array}$ & Nature & Pancreatic \\
\hline Adduri & 2014 & $\begin{array}{l}\text { P53 nuclear stabilization is associated with } \\
\text { FHIT loss and younger age of onset in } \\
\text { squamous cell carcinoma of oral tongue }\end{array}$ & BMC Clinical Pathology & Oral cavity \\
\hline Akbari & 2017 & $\begin{array}{l}\text { Correlation between germline mutations in } \\
\text { MMR genes and microsatellite instability in } \\
\text { ovarian cancer specimens }\end{array}$ & Familial Cancer & Ovarian \\
\hline Alldinger & 2007 & $\begin{array}{l}\text { Microsatellite instability in Ewing tumor is not } \\
\text { associated with loss of mismatch repair protein } \\
\text { expression }\end{array}$ & $\begin{array}{l}\text { Journal of Cancer Research and } \\
\text { Clinical Oncology }\end{array}$ & Ewing sarcoma \\
\hline Altavilla & 2010 & $\begin{array}{l}\text { Microsatellite instability and hMLH1 and } \\
\text { hMSH2 expression in renal tumors }\end{array}$ & Oncology Reports & Renal \\
\hline Amaki-Takao & 2016 & $\begin{array}{c}\text { Colorectal cancer with BRAF D } 594 \mathrm{G} \text { mutation } \\
\text { is not associated with microsatellite instability } \\
\text { or poor prognosis }\end{array}$ & Oncology (Switzerland) & Colorectal \\
\hline An & 2005 & $\begin{array}{l}\text { Prognostic significance of } \mathrm{CpG} \text { island } \\
\text { methylator phenotype and microsatellite } \\
\text { instability in gastric carcinoma }\end{array}$ & Clinical Cancer Research & Gastric \\
\hline An & 2012 & $\begin{array}{l}\text { Microsatellite instability in sporadic gastric } \\
\text { cancer: its prognostic role and guidance for 5- } \\
\text { fu based chemotherapy after r0 resection }\end{array}$ & International Journal of Cancer & Gastric \\
\hline Aparicio & 2013 & $\begin{array}{l}\text { Small bowel adenocarcinoma phenotyping, a } \\
\text { clinicobiological prognostic study }\end{array}$ & British Journal of Cancer & Small bowel \\
\hline Aysal & 2012 & $\begin{array}{l}\text { Ovarian endometrioid adenocarcinoma: } \\
\text { incidence and clinical significance of the } \\
\text { morphologic and immunohistochemical } \\
\text { markers of mismatch repair protein defects and } \\
\text { tumor microsatellite instability }\end{array}$ & $\begin{array}{l}\text { The American Journal of Surgical } \\
\text { Pathology }\end{array}$ & Ovarian \\
\hline Bacani & 2005 & $\begin{array}{c}\text { Tumor microsatellite instability in early onset } \\
\text { gastric cancer }\end{array}$ & Journal of Molecular Diagnostics & Gastric \\
\hline Bae & 2015 & $\begin{array}{c}\text { Usefulness of immunohistochemistry for } \\
\text { microsatellite instability screening in gastric } \\
\text { cancer }\end{array}$ & Gut and Liver & Gastric \\
\hline Basil & 2000 & $\begin{array}{l}\text { Clinical significance of microsatellite instability } \\
\text { in endometrial carcinoma }\end{array}$ & Cancer & Endometrial \\
\hline Bataille & 2003 & $\begin{array}{l}\text { Alterations in p53 predict response to } \\
\text { preoperative high dose chemotherapy in } \\
\text { patients with gastric cancer }\end{array}$ & $\begin{array}{l}\text { Journal of Clinical Pathology- } \\
\text { Molecular Pathology }\end{array}$ & Gastric \\
\hline Billingsley & 2015 & $\begin{array}{c}\text { Polymerase e (pole) mutations in endometrial } \\
\text { cancer: clinical outcomes and implications for } \\
\text { Lynch syndrome testing } \\
\text { Clinicopathologic significance of defective }\end{array}$ & Cancer & Endometrial \\
\hline Black & 2006 & $\begin{array}{l}\text { DNA mismatch repair in endometrial } \\
\text { carcinoma }\end{array}$ & Journal of Clinical Oncology & Endometrial \\
\hline Buller & 2001 & $\begin{array}{l}\text { p53 mutations and microsatellite instability in } \\
\text { ovarian cancer: Yin and Yang }\end{array}$ & $\begin{array}{l}\text { American Journal of Obstetrics \& } \\
\text { Gynecology }\end{array}$ & Ovarian \\
\hline Buttin & 2006 & $\begin{array}{l}\text { Increased risk for abnormalities on } \\
\text { perioperative colon screening in patients with } \\
\text { microsatellite instability-positive endometrial } \\
\text { carcinoma }\end{array}$ & $\begin{array}{c}\text { International Journal of Gynecological } \\
\text { Cancer }\end{array}$ & Endometrial \\
\hline Cai & 2004 & $\begin{array}{l}\text { Microsatellite instability and alteration of the } \\
\text { expression of hMLH1 and hMSH2 in ovarian } \\
\text { clear cell carcinoma }\end{array}$ & Human Pathology & Ovarian \\
\hline Catasus & 2004 & $\begin{array}{l}\text { Molecular genetic alterations in endometrioid } \\
\text { carcinomas of the ovary: similar frequency of } \\
\text { beta-catenin abnormalities but lower rate of } \\
\text { microsatellite instability and PTEN alterations } \\
\text { than in uterine endometrioid carcinomas }\end{array}$ & Human Pathology & Ovarian \\
\hline
\end{tabular}


TABle 2: Continued.

\begin{tabular}{|c|c|c|c|c|}
\hline Author & Year & Title & Journal & Tumor type \\
\hline Cesinaro & 2007 & $\begin{array}{l}\text { Mismatch repair proteins expression and } \\
\text { microsatellite instability in skin lesions with } \\
\text { sebaceous differentiation: a study in different } \\
\text { clinical subgroups with and without } \\
\text { extracutaneous cancer }\end{array}$ & $\begin{array}{c}\text { The American Journal of } \\
\text { Dermatopathology }\end{array}$ & Sebaceous \\
\hline Chiaravalli & 2001 & $\begin{array}{l}\text { Immunohistochemical pattern of hMSH2/ } \\
\text { hMLH1 in familial and sporadic colorectal, } \\
\text { gastric, endometrial and ovarian carcinomas } \\
\text { with instability in microsatellite sequences }\end{array}$ & Virchows Archiv & $\begin{array}{l}\text { Gastric, endometrial, } \\
\text { ovarian, and colorectal }\end{array}$ \\
\hline Choe & 2005 & $\begin{array}{c}\text { High frequency of microsatellite instability in } \\
\text { intestinal-type gastric cancer in Korean } \\
\text { patients }\end{array}$ & $\begin{array}{l}\text { The Korean Journal of Internal } \\
\text { Medicine }\end{array}$ & Gastric \\
\hline Choi & 2015 & $\begin{array}{l}\text { Correlation between microsatellite instability- } \\
\text { high phenotype and occult lymph node } \\
\text { metastasis in gastric carcinoma }\end{array}$ & APMIS & Gastric \\
\hline Chong & 2013 & $\begin{array}{l}\text { The genomic landscape of oesophagogastric } \\
\text { junctional adenocarcinoma }\end{array}$ & Journal of Pathology & $\begin{array}{l}\text { Oesophagogastric } \\
\text { junctional }\end{array}$ \\
\hline Choy & 2004 & $\begin{array}{l}\text { Microsatellite instability and MLH1 promoter } \\
\text { methylation in human retinoblastoma }\end{array}$ & $\begin{array}{l}\text { Investigative Ophthalmology and } \\
\text { Visual science }\end{array}$ & Retinoblastoma \\
\hline Cook & 2013 & $\begin{array}{l}\text { Endometrial cancer and a family history of } \\
\text { cancer }\end{array}$ & Gynecologic Oncology & $\begin{array}{l}\text { Endometrial and other } \\
\text { unspecified tumors }\end{array}$ \\
\hline Cullinane & 2004 & $\begin{array}{l}\text { Microsatellite instability is a rare finding in } \\
\text { tumors of patients with both primary renal and } \\
\text { rectal neoplasms }\end{array}$ & Cancer Genetics \& Cytogenetics & Rectal and renal \\
\hline Dewdney & 2012 & $\begin{array}{l}\text { Uterine serous carcinoma: increased familial } \\
\text { risk for Lynch-associated malignancies }\end{array}$ & Cancer Prevention Research & Endometrial \\
\hline Evans & 2004 & $\begin{array}{c}\text { Microsatellite instability in esophageal } \\
\text { adenocarcinoma }\end{array}$ & Cancer Letters & Esophageal \\
\hline $\mathrm{Fu}$ & 2012 & $\begin{array}{l}\text { Cpg island methylator phenotype-positive } \\
\text { tumors in the absence of mlh1 methylation } \\
\text { constitute a distinct subset of duodenal } \\
\text { adenocarcinomas and are associated with poor } \\
\text { prognosis }\end{array}$ & Clinical Cancer Research & Small bowel \\
\hline Garcia & 2006 & $\begin{array}{c}\text { Mismatch repair protein expression and } \\
\text { microsatellite instability: a comparison of clear } \\
\text { cell sarcoma of soft parts and metastatic } \\
\text { melanoma }\end{array}$ & Modern Pathology & $\begin{array}{l}\text { Clear Cell Sarcoma and } \\
\text { Melanoma }\end{array}$ \\
\hline Gargano & 2007 & $\begin{array}{l}\text { Aberrant methylation within RUNX3 CpG } \\
\text { island associated with the nuclear and } \\
\text { mitochondrial microsatellite instability in } \\
\text { sporadic gastric cancers. Results of a GOIM } \\
\text { (gruppo oncologico dell'italia meridionale) } \\
\text { prospective study }\end{array}$ & Annals of Oncology & Gastric \\
\hline Geiseler & 2003 & $\begin{array}{l}\text { Mismatch repair gene expression defects } \\
\text { contribute to microsatellite instability in } \\
\text { ovarian carcinoma }\end{array}$ & Cancer & Ovarian \\
\hline Glavac & 2003 & $\begin{array}{l}\text { Low microsatellite instability and high loss of } \\
\text { heterozygosity rates indicate dominant role of } \\
\text { the suppressor pathway in squamous cell } \\
\text { carcinoma of head and neck and loss of } \\
\text { heterozygosity of 11q14.3 correlates with } \\
\text { tumor grade }\end{array}$ & Cancer Genetics \& Cytogenetics & Head and neck \\
\hline Goodfellow & 2003 & $\begin{array}{l}\text { Prevalence of defective DNA mismatch repair } \\
\text { and MSH6 mutation in an unselected series of } \\
\text { endometrial cancers }\end{array}$ & $\begin{array}{c}\text { Proceedings of the National Academy } \\
\text { of Sciences of the United States of } \\
\text { America }\end{array}$ & Endometrial \\
\hline Gras & 2001 & $\begin{array}{l}\text { Microsatellite instability, MLH-1 promoter } \\
\text { hypermethylation, and frameshift mutations at } \\
\text { coding mononucleotide repeat microsatellites } \\
\text { in ovarian tumors }\end{array}$ & Cancer & Ovarian \\
\hline
\end{tabular}


TABle 2: Continued.

\begin{tabular}{|c|c|c|c|c|}
\hline Author & Year & Title & Journal & Tumor type \\
\hline Grogg & 2003 & $\begin{array}{l}\text { Lymphocyte-rich gastric cancer: associations } \\
\text { with Epstein-Barr virus, microsatellite } \\
\text { instability, histology, and survival }\end{array}$ & Modern Pathology & Gastric \\
\hline $\mathrm{Gu}$ & 2009 & $\begin{array}{l}\text { Analysis of microsatellite instability, protein } \\
\text { expression and methylation status of hmlh1 } \\
\text { and hmsh2 genes in gastric carcinomas }\end{array}$ & Hepato-Gastroenterology & Gastric \\
\hline Hampel & 2005 & $\begin{array}{l}\text { Screening for the Lynch syndrome (hereditary } \\
\text { nonpolyposis colorectal cancer) }\end{array}$ & The New England Journal of Medicine & Colorectal \\
\hline Hasuo & 2007 & $\begin{array}{l}\text { Assessment of microsatellite instability status } \\
\text { for the prediction of metachronous recurrence } \\
\text { after initial endoscopic submucosal dissection } \\
\text { for early gastric cancer }\end{array}$ & British Journal of Cancer & Gastric \\
\hline Hermsen & 2009 & $\begin{array}{l}\text { Genome-wide analysis of genetic changes in } \\
\text { intestinal-type sinonasal adenocarcinoma } \\
\text { Microsatellite instability, mismatch repair }\end{array}$ & Head \& neck & Nasopharynx \\
\hline Honecker & 2009 & $\begin{array}{l}\text { deficiency, and BRAF mutation in treatment- } \\
\text { resistant germ cell tumors }\end{array}$ & Journal of Clinical Oncology & Testis \\
\hline Hong & 2012 & $\begin{array}{l}\text { The differential impact of microsatellite } \\
\text { instability as a marker of prognosis and tumour } \\
\text { response between colon cancer and rectal } \\
\text { cancer }\end{array}$ & European Journal of Cancer & Colorectal \\
\hline Huang & 2010 & $\begin{array}{c}\text { Comparative features of colorectal and gastric } \\
\text { cancers with microsatellite instability in } \\
\text { Chinese patients }\end{array}$ & Journal of Zhejiang University Science & Gastric and colorectal \\
\hline Jahng & 2012 & $\begin{array}{c}\text { Endoscopic and clinicopathologic } \\
\text { characteristics of early gastric cancer with high } \\
\text { microsatellite instability }\end{array}$ & World Journal of Gastroenterology & Gastric \\
\hline Jensen & 2008 & $\begin{array}{l}\text { Microsatellite instability and mismatch repair } \\
\text { protein defects in ovarian epithelial neoplasms } \\
\text { in patients } 50 \text { years of age and younger }\end{array}$ & $\begin{array}{c}\text { American Journal of surgical } \\
\text { Pathology }\end{array}$ & Ovarian \\
\hline Jung & $2016 a$ & $\begin{array}{l}\text { Prognostic impact of microsatellite instability } \\
\text { in colorectal cancer presenting with mucinous, } \\
\text { signet-ring, and poorly differentiated cells }\end{array}$ & Annals of Coloproctology & Colorectal \\
\hline Jung & $2016 b$ & $\begin{array}{l}\text { Observational study: familial relevance and } \\
\text { oncological significance of revised bethesda } \\
\text { guidelines in colorectal patients that have } \\
\text { undergone curative resection }\end{array}$ & Medicine (United States) & Colorectal \\
\hline Kanopiene & 2014 & $\begin{array}{l}\text { Impact of microsatellite instability on survival } \\
\text { of endometrial cancer patients }\end{array}$ & Medicina & Endometrial \\
\hline $\begin{array}{l}\text { Karpińska- } \\
\text { Kaczmarczyk }\end{array}$ & 2016 & $\begin{array}{l}\text { Expression of mismatch repair proteins in early } \\
\text { and advanced gastric cancer in Poland }\end{array}$ & Medical Science Monitor & Gastric \\
\hline Kawaguchi & 2009 & $\begin{array}{c}\text { Analysis of candidate target genes for } \\
\text { mononucleotide repeat mutation in } \\
\text { microsatellite instability-high (MSI-H) } \\
\text { endometrial cancer }\end{array}$ & International Journal of Oncology & Endometrial \\
\hline Kawanaka & 2016 & $\begin{array}{c}\text { Effects of Helicobacter pylori eradication on } \\
\text { the development of metachronous gastric } \\
\text { cancer after endoscopic treatment: analysis of } \\
\text { molecular alterations by a randomised } \\
\text { controlled trial }\end{array}$ & British Journal of Cancer & Gastric \\
\hline Kim & 1999 & $\begin{array}{c}\text { Accumulated frameshift mutations at coding } \\
\text { nucleotide repeats during the progression of } \\
\text { gastric carcinoma with microsatellite } \\
\text { instability }\end{array}$ & Laboratory Investigation & Gastric \\
\hline Kim & $2013 a$ & $\begin{array}{l}\text { Microsatellite instability status in gastric } \\
\text { cancer: a reappraisal of its clinical significance } \\
\text { and relationship with mucin phenotypes }\end{array}$ & Korean Journal of Pathology & Gastric \\
\hline Kim & $2013 b$ & $\begin{array}{l}\text { Differential clinicopathologic features in } \\
\text { microsatellite-unstable gastric cancers with } \\
\text { and without MLH1 methylation }\end{array}$ & Human Pathology & Gastric \\
\hline
\end{tabular}


TABle 2: Continued.

\begin{tabular}{|c|c|c|c|c|}
\hline Author & Year & Title & Journal & Tumor type \\
\hline Kim & $2016 a$ & $\begin{array}{l}\text { Clinicopathologic features of gastric cancer } \\
\text { with synchronous and metachronous } \\
\text { colorectal cancer in Korea: are microsatellite } \\
\text { instability and p53 overexpression useful } \\
\text { markers for predicting colorectal cancer in } \\
\text { gastric cancer patients? }\end{array}$ & Gastric Cancer & Gastric and colorectal \\
\hline Kim & $2016 b$ & $\begin{array}{l}\text { Microsatellite instability of gastric and } \\
\text { colorectal cancers as a predictor of } \\
\text { synchronous gastric or colorectal neoplasms }\end{array}$ & Gut and Liver & Gastric and colorectal \\
\hline Koopman & 2009 & $\begin{array}{l}\text { Deficient mismatch repair system in patients } \\
\text { with sporadic advanced colorectal cancer }\end{array}$ & British Journal of Cancer & Colorectal \\
\hline Kubo & 2005 & $\begin{array}{c}\text { Frequent microsatellite instability in primary } \\
\text { esophageal carcinoma associated with } \\
\text { extraesophageal primary carcinoma }\end{array}$ & International Journal of Cancer & Esophageal \\
\hline Kumagai & 2015 & $\begin{array}{l}\text { Mucinous phenotype and cd10 expression of } \\
\text { primary adenocarcinoma of the small intestine }\end{array}$ & World Journal of Gastroenterology & Small bowel \\
\hline Leenen & 2012 & $\begin{array}{l}\text { Prospective evaluation of molecular screening } \\
\text { for Lynch syndrome in patients with } \\
\text { endometrial cancer } \leq 70 \text { years }\end{array}$ & Gynecologic Oncology & Endometrial \\
\hline Leite & 2011 & $\begin{array}{l}\text { MSI phenotype and MMR alterations in } \\
\text { familial and sporadic gastric cancer }\end{array}$ & International Journal of Cancer & Gastric \\
\hline Liu & 2004 & $\begin{array}{l}\text { Microsatellite instability and expression of } \\
\text { hMLH1 and hMSH2 proteins in ovarian } \\
\text { endometrioid cancer }\end{array}$ & Modern Pathology & Ovarian \\
\hline $\mathrm{Lu}$ & 2007 & $\begin{array}{c}\text { Prospective determination of prevalence of } \\
\text { Lynch syndrome in young women with } \\
\text { endometrial cancer }\end{array}$ & Journal of Clinical Oncology & Endometrial \\
\hline Martinez & 2005 & $\begin{array}{l}\text { Low-level microsatellite instability phenotype } \\
\text { in sporadic glioblastoma multiforme }\end{array}$ & $\begin{array}{l}\text { Journal of Cancer Research and } \\
\text { Clinical Oncology }\end{array}$ & Brain \\
\hline Mathiak & 2017 & $\begin{array}{l}\text { Clinicopathologic characteristics of } \\
\text { microsatellite instable gastric carcinomas } \\
\text { revisited: urgent need for standardization }\end{array}$ & $\begin{array}{l}\text { Applied Immunohistochemistry and } \\
\text { Molecular Morphology }\end{array}$ & Gastric \\
\hline Matsumoto & 2007 & $\begin{array}{c}\text { Microsatellite instability and } \\
\text { clinicopathological features in esophageal } \\
\text { squamous cell cancer }\end{array}$ & Oncology Reports & Esophageal \\
\hline McCleary & 2016 & $\begin{array}{c}\text { Prognostic utility of molecular factors by age at } \\
\text { diagnosis of colorectal cancer }\end{array}$ & Clinical Cancer Research & Colorectal \\
\hline McConechy & 2015 & $\begin{array}{l}\text { Detection of DNA mismatch repair (mmr) } \\
\text { deficiencies by immunohistochemistry can } \\
\text { effectively diagnose the microsatellite } \\
\text { instability (msi) phenotype in endometrial } \\
\text { carcinomas }\end{array}$ & Gynecologic Oncology & Endometrial \\
\hline McCourt & 2007 & $\begin{array}{l}\text { Body mass index: relationship to clinical, } \\
\text { pathologic and features of microsatellite } \\
\text { instability in endometrial cancer }\end{array}$ & Gynecologic Oncology & Endometrial \\
\hline Moy & 2015 & $\begin{array}{c}\text { Microsatellite instability in gallbladder } \\
\text { carcinoma }\end{array}$ & Virchows Archiv & Gallbladder \\
\hline Nagahashi & 2008 & $\begin{array}{c}\text { Genetic changes of } \mathrm{p} 53, \mathrm{Kras} \text {, and } \\
\text { microsatellite instability in gallbladder } \\
\text { carcinoma in high-incidence areas of Japan and } \\
\text { Hungary }\end{array}$ & World Journal of Gastroenterology & Gallbladder \\
\hline Okuda & 2005 & $\begin{array}{l}\text { The profile of hMLH1 methylation and } \\
\text { microsatellite instability in colorectal and non- } \\
\text { small cell lung cancer }\end{array}$ & $\begin{array}{c}\text { International Journal of Molecular } \\
\text { Medicine }\end{array}$ & Colorectal, NSCLC \\
\hline Rajan & 2014 & $\begin{array}{c}\text { DNA mismatch repair defects and } \\
\text { microsatellite instability status in periocular } \\
\text { sebaceous carcinoma }\end{array}$ & American Journal of Ophthalmology & Sebaceous \\
\hline Roa & 2005 & $\begin{array}{l}\text { Microsatellite instability in preneoplastic and } \\
\text { neoplastic lesions of the gallbladder }\end{array}$ & Journal of Gastroenterology & Gallbladder \\
\hline
\end{tabular}


TABle 2: Continued.

\begin{tabular}{|c|c|c|c|c|}
\hline Author & Year & Title & Journal & Tumor type \\
\hline $\begin{array}{l}\text { Rodriguez- } \\
\text { Hernandez }\end{array}$ & 2013 & $\begin{array}{c}\text { Integrated analysis of mismatch repair system } \\
\text { in malignant astrocytomas }\end{array}$ & PLoS One (electronic resource) & Brain \\
\hline Rubio & 2016 & $\begin{array}{l}\text { Analysis of Lynch syndrome mismatch repair } \\
\text { genes in women with endometrial cancer }\end{array}$ & Oncology & Endometrial \\
\hline $\begin{array}{l}\text { Rubio-Del- } \\
\text { Campo }\end{array}$ & 2008 & $\begin{array}{l}\text { Implications of mismatch repair genes hmlh1 } \\
\text { and hmsh2 in patients with sporadic renal cell } \\
\text { carcinoma }\end{array}$ & BJU international & Renal \\
\hline Ruemmele & 2009 & $\begin{array}{l}\text { Histopathologic features and microsatellite } \\
\text { instability of cancers of the papilla of vater and } \\
\text { their precursor lesions }\end{array}$ & $\begin{array}{l}\text { The American Journal of Survival } \\
\text { Pathology }\end{array}$ & Pancreatic \\
\hline Saetta & 2004 & $\begin{array}{l}\text { Mononucleotide markers of microsatellite } \\
\text { instability in carcinomas of the urinary bladder } \\
\text { Microsatellite instability, prognosis and }\end{array}$ & $\begin{array}{l}\text { European Journal of Surgical } \\
\text { Oncology }\end{array}$ & Bladder \\
\hline Schneider & 2000 & $\begin{array}{c}\text { metastasis in gastric cancers from a low-risk } \\
\text { population }\end{array}$ & International Journal of Cancer & Gastric \\
\hline Seo & 2009 & $\begin{array}{c}\text { Clinicopathologic characteristics and } \\
\text { outcomes of gastric cancers with the MSI-H } \\
\text { phenotype }\end{array}$ & Journal of Surgical Oncology & Gastric \\
\hline Seo & 2015 & $\begin{array}{l}\text { Clinicopathologic and molecular features } \\
\text { associated with patient age in gastric cancer }\end{array}$ & World Journal of Gastroenterology & Gastric \\
\hline Shibata & 2006 & $\begin{array}{c}\text { RAB32 hypermethylation and microsatellite } \\
\text { instability in gastric and endometrial } \\
\text { adenocarcinomas }\end{array}$ & International Journal of Cancer & $\begin{array}{l}\text { Gastric and } \\
\text { endometrial }\end{array}$ \\
\hline Shilpa & 2014 & $\begin{array}{c}\text { Microsatellite instability, promoter } \\
\text { methylation and protein expression of the } \\
\text { DNA mismatch repair genes in epithelial } \\
\text { ovarian cancer }\end{array}$ & Genomics & Ovarian \\
\hline Shirai & 2006 & $\begin{array}{l}\text { Interleukin- } 8 \text { gene polymorphism associated } \\
\text { with susceptibility to non-cardia gastric } \\
\text { carcinoma with microsatellite instability }\end{array}$ & $\begin{array}{l}\text { Journal of Gastroenterology and } \\
\text { Hepatology (Australia) }\end{array}$ & Gastric \\
\hline Singer & 2004 & $\begin{array}{c}\text { Different types of microsatellite instability in } \\
\text { ovarian carcinoma }\end{array}$ & International Journal of Cancer & Ovarian \\
\hline Skenderi & 2017 & $\begin{array}{l}\text { Warthin-like papillary renal cell carcinoma: } \\
\text { Clinicopathologic, morphologic, } \\
\text { immunohistochemical and molecular genetic } \\
\text { analysis of } 11 \text { cases }\end{array}$ & Annals of Diagnostic Pathology & Renal \\
\hline Soliman & 2005 & $\begin{array}{c}\text { Women with synchronous primary cancers of } \\
\text { the endometrium and ovary: do they have } \\
\text { Lynch syndrome? }\end{array}$ & $\begin{array}{l}\text { Journal of Clinical Oncology: Official } \\
\text { Journal of the American Society of } \\
\text { Clinical Oncology }\end{array}$ & $\begin{array}{l}\text { Endometrial and } \\
\text { ovarian }\end{array}$ \\
\hline Sood & 2001 & $\begin{array}{l}\text { Application of the National Cancer Institute } \\
\text { international criteria for determination of } \\
\text { microsatellite instability in ovarian cancer }\end{array}$ & Cancer Research & Ovarian \\
\hline Stello & 2016 & $\begin{array}{l}\text { Improved risk assessment by integrating } \\
\text { molecular and clinicopathological factors in } \\
\text { early-stage endometrial cancer-combined } \\
\text { analysis of the PORTEC cohorts }\end{array}$ & Clinical Cancer Research & Endometrial \\
\hline Stoehr & 2012 & $\begin{array}{l}\text { Mismatch repair proteins hMLH1 and hMSH2 } \\
\text { are differently expressed in the three main } \\
\text { subtypes of sporadic renal cell carcinoma }\end{array}$ & Pathobiology & Renal \\
\hline Suemori & 2015 & $\begin{array}{l}\text { Intratumoral cd } 8+\text { lymphocyte infiltration as a } \\
\text { prognostic factor and its relationship with } \\
\text { cyclooxygenase } 2 \text { expression and microsatellite } \\
\text { instability in endometrial cancer }\end{array}$ & $\begin{array}{l}\text { International Journal of Gynecological } \\
\text { Cancer }\end{array}$ & Endometrial \\
\hline Sugai & 2017 & $\begin{array}{c}\text { Genetic differences stratified by PCR-based } \\
\text { microsatellite analysis in gastric intramucosal } \\
\text { neoplasia }\end{array}$ & Gastric Cancer & Gastric \\
\hline Tanaka & 2006 & $\begin{array}{c}\text { Effect of eradication of Helicobacter pylori on } \\
\text { genetic instabilities in gastric intestinal } \\
\text { metaplasia }\end{array}$ & $\begin{array}{l}\text { Alimentary Pharmacology and } \\
\text { Therapeutics Symposium Series }\end{array}$ & Gastric \\
\hline
\end{tabular}


TABLE 2: Continued.

\begin{tabular}{|c|c|c|c|c|}
\hline Author & Year & Title & Journal & Tumor type \\
\hline Tay & 2003 & $\begin{array}{c}\text { A combined comparative genomic } \\
\text { hybridization and expression microarray } \\
\text { analysis of gastric cancer reveals novel } \\
\text { molecular subtypes }\end{array}$ & Cancer Research & Gastric \\
\hline Vladimirova & 2008 & $\begin{array}{l}\text { Low level of microsatellite instability in } \\
\text { paediatric malignant astrocytomas }\end{array}$ & $\begin{array}{l}\text { Neuropathology and Applied } \\
\text { Neurobiology }\end{array}$ & Brain \\
\hline Wen & 2012 & $\begin{array}{l}\text { DNA mismatch repair deficiency in breast } \\
\text { carcinoma a pilot study of triple-negative and } \\
\text { non-triple-negative tumors }\end{array}$ & $\begin{array}{l}\text { The American Journal of Survival } \\
\text { Pathology }\end{array}$ & Breast \\
\hline Wong & 2003 & $\begin{array}{l}\text { The role of microsatellite instability in cervical } \\
\text { intraepithelial neoplasia and squamous cell } \\
\text { carcinoma of the cervix }\end{array}$ & Gynecologic Oncology & Cervical \\
\hline Yan & 2016 & $\begin{array}{l}\text { Prediction of biological behavior and prognosis } \\
\text { of colorectal cancer patients by tumor msi/ } \\
\mathrm{mmr} \text { in the Chinese population }\end{array}$ & OncoTargets and Therapy & Colorectal \\
\hline Yoon & 2008 & $\begin{array}{l}\text { Clinical significance of microsatellite instability } \\
\text { in sporadic epithelial ovarian tumors }\end{array}$ & Yonsei Medical Journal & Ovarian \\
\hline Zighelboim & 2007 & $\begin{array}{c}\text { Microsatellite instability and epigenetic } \\
\text { inactivation of MLH1 and outcome of patients } \\
\text { with endometrial carcinomas of the } \\
\text { endometrioid type }\end{array}$ & Journal of Clinical Oncology & Endometrial \\
\hline
\end{tabular}

and esophageal (6 studies). Twenty CRC studies were identified from the targeted review. Overall, 54 studies were conducted in the United States, 18 in Korea, 12 in Japan, 12 in multiple countries, and 60 in other countries. Most studies provided an MSI-H cut-off between 30 and $40 \%$, inclusive, translating into a change in loci size of greater than or equal to 2 of 5 loci tested; however, there were two prominent outliers at 9\% (Glavac 2003) and 66\% (Wen 2012). Fifty-four studies used all four MMR proteins to detect MMR status, 3 studies used three proteins, 6 studies used two proteins, and 3 studies did not specify number of proteins used. Included studies reported different study designs: case control, cross-sectional, prospective cohort, and retrospective cohort.

3.3. Patient Characteristics. Across studies, the mean/median age ranged from 20.7 to 74 years. Percentage of patients by ethnicity ranged as follows: Caucasian (0-94.8\%), African American (0-17.2\%), Asian (0-100\%), and other ethnic groups $(0-13.8 \%)$. In studies where disease stage was reported, percentage of patients with stage 1 disease ranged from 0 to $80.7 \%$, stage 2 disease ranged from 4.2 to $38.6 \%$, stage 3 disease ranged from 8 to $73.5 \%$, and stage 4 disease ranged from 0 to $97.7 \%$.

3.4. MSI-H and dMMR Prevalence. The number of studies with available MSI-H and dMMR data is presented in Table 5. Of the 156 included studies, MSI-H prevalence as determined by NCI or Promega markers was reported in 90 studies, and MSS prevalence was reported in 79 studies. Sixty-six studies reported dMMR prevalence; 54 of those used all 4 MMR proteins in the IHC assay. Pooled MSI-H and dMMR prevalence estimates were reported in 140 studies.
MSI-H prevalence was available in 25 studies conducted in the United States, 17 studies conducted in Korea, and 8 studies conducted in Japan. dMMR prevalence data were available in 27 conducted in the United States and 2 studies conducted in Japan. MSI-H prevalence was reported by stages 1 (18 studies), 2 (18 studies), 3 (17 studies), 4 (16 studies), 1 or 2 (24 studies), and 3 or 4 (23 studies).

Beyond the 6 main tumor types feasible for tumorspecific meta-analyses, 19 other tumor types were included in the meta-analysis of overall MSI-H prevalence. Overall, MSI-H prevalence differed considerably across tumor types. A low prevalence of $2 \%$ (95\% CI, 0\%-8\%) was observed in Ewing sarcoma [19], while a much higher prevalence of $35 \%$ (95\% CI, 15\%-57\%) was reported in sebaceous tumors [20]. Small bowel [21] and cervical tumors [22] had prevalence of $12 \%$ each, which were very close to the all-tumor estimate.

3.5. Meta-Analysis Results: Random Effects. Overall metaanalysis results is presented in Figure 2. Prevalence estimates, 95\% confidence intervals, and number of studies included in each analysis are shown. Meta-analysis results obtained from the random effects model in all tumor types are presented as forest plots in the Supplementary information (Appendix Figures 1-Figure 26). Funnel plots obtained from each meta-analysis are also presented in the Supplementary information (Appendix Figure 27-Figure 44).

The weighted prevalence of MSI-H without genomic studies was estimated to be $14 \%$ (95\% CI, 10\%-19\%) across all tumor types and stages. The prevalence was $10 \%(95 \% \mathrm{CI}$, $7 \%-14 \%)$ when four of the five large pan-tumor genomic studies were included (one genomic study was excluded as it did not report the total number of patients or the number of patients with MSI-H). Overall weighted dMMR prevalence was estimated to be $16 \%(95 \%$ CI, $11 \%-22 \%)$ across all 
TABLE 3: References-MMR studies.

\begin{tabular}{|c|c|c|c|c|}
\hline Author & Year & Title & Journal & Tumor type \\
\hline Backes & 2009 & $\begin{array}{l}\text { Prospective evaluation of DNA mismatch repair protein } \\
\text { expression in primary endometrial cancer }\end{array}$ & Gynecologic Oncology & Endometrial \\
\hline Bennett & 2016 & $\begin{array}{c}\text { Mismatch repair protein expression in clear cell } \\
\text { carcinoma of the ovary: incidence and morphologic } \\
\text { associations in } 109 \text { cases }\end{array}$ & $\begin{array}{l}\text { The American Journal of } \\
\text { Surgical Pathology }\end{array}$ & Ovarian \\
\hline Bhosale & 2017 & $\begin{array}{l}\text { Can reduced field-of-view diffusion sequence help assess } \\
\text { microsatellite instability in FIGO stage } 1 \text { endometrial } \\
\text { cancer? }\end{array}$ & $\begin{array}{l}\text { Journal of Magnetic Resonance } \\
\text { Imaging }\end{array}$ & Endometrial \\
\hline Brady & 2017 & $\begin{array}{l}\text { Sebaceous carcinoma treated with Mohs micrographic } \\
\text { surgery }\end{array}$ & Dermatologic Surgery & Sebaceous \\
\hline Bregar & 2017 & $\begin{array}{l}\text { Characterization of immune regulatory molecules b7-h4 } \\
\text { and pd-11 in low and high grade endometrial tumors }\end{array}$ & Gynecologic Oncology & Endometrial \\
\hline Bruegl & 2014 & $\begin{array}{c}\text { Evaluation of clinical criteria for the identification of } \\
\text { Lynch syndrome among unselected patients with } \\
\text { endometrial cancer }\end{array}$ & Cancer Prevention Research & Endometrial \\
\hline Bruegl & 2017 & $\begin{array}{l}\text { Clinical challenges associated with universal screening } \\
\text { for Lynch syndrome-associated endometrial cancer }\end{array}$ & Cancer Prevention Research & Endometrial \\
\hline Buchanan & 2014 & $\begin{array}{l}\text { Tumor mismatch repair immunohistochemistry and } \\
\text { DNA mlh1 methylation testing of patients with } \\
\text { endometrial cancer diagnosed at age younger than } 60 \\
\text { years optimizes triage for population-level germline } \\
\text { mismatch repair gene mutation testing }\end{array}$ & Journal of Clinical Oncology & Endometrial \\
\hline Carleton & 2016 & $\begin{array}{c}\text { A detailed immunohistochemical analysis of a large } \\
\text { series of cervical and vaginal gastric-type } \\
\text { adenocarcinomas }\end{array}$ & $\begin{array}{l}\text { The American Journal of } \\
\text { Surgical pathology }\end{array}$ & Cervical and vaginal \\
\hline Chen & 2017 & $\begin{array}{l}\text { Immunohistochemical profiling of endometrial serous } \\
\text { carcinoma }\end{array}$ & $\begin{array}{l}\text { International Journal of } \\
\text { Gynecological Pathology }\end{array}$ & Endometrial \\
\hline Clay & 2014 & $\begin{array}{l}\text { Risk of secondary malignancy (including breast) in } \\
\text { patients with mismatch-repair protein deficiency }\end{array}$ & $\begin{array}{l}\text { The American Journal of } \\
\text { Surgical pathology }\end{array}$ & Endometrial \\
\hline Connor & 2017 & $\begin{array}{c}\text { Association of distinct mutational signatures with } \\
\text { correlates of increased immune activity in pancreatic } \\
\text { ductal adenocarcinoma }\end{array}$ & JAMA Oncology & Pancreatic \\
\hline Djordjevic & 2013 & $\begin{array}{l}\text { Relationship between PTEN, DNA mismatch repair, and } \\
\text { tumor histotype in endometrial carcinoma: retained } \\
\text { positive expression of PTEN preferentially identifies } \\
\text { sporadic non-endometrioid carcinomas }\end{array}$ & Modern Pathology & Endometrial \\
\hline Everett & 2014 & $\begin{array}{l}\text { Screening for germline mismatch repair mutations } \\
\text { following diagnosis of sebaceous neoplasm }\end{array}$ & JAMA Dermatology & Sebaceous \\
\hline Gaskin & 2011 & $\begin{array}{l}\text { The significance of DNA mismatch repair genes in the } \\
\text { diagnosis and management of periocular sebaceous cell } \\
\text { carcinoma and Muir-Torre syndrome }\end{array}$ & $\begin{array}{l}\text { British Journal of } \\
\text { Ophthalmology }\end{array}$ & Sebaceous \\
\hline Goldberg & 2017 & $\begin{array}{c}\text { Microcystic, elongated, and fragmented pattern invasion } \\
\text { in ovarian endometrioid carcinoma: } \\
\text { immunohistochemical profile and prognostic } \\
\text { implications }\end{array}$ & $\begin{array}{l}\text { International Journal of } \\
\text { Gynecological Pathology }\end{array}$ & Ovarian \\
\hline Grzankowski & 2012 & $\begin{array}{l}\text { Clinical and pathologic features of young endometrial } \\
\text { cancer patients with loss of mismatch repair expression }\end{array}$ & Gynecologic Oncology & Endometrial \\
\hline Joehlin-Price & 2014 & $\begin{array}{c}\text { Mismatch repair protein expression in } 1049 \text { endometrial } \\
\text { carcinomas, associations with body mass index, and } \\
\text { other clinicopathologic variables }\end{array}$ & Gynecologic Oncology & Endometrial \\
\hline Kato & 2015 & $\begin{array}{l}\text { DNA mismatch repair-related protein loss as a } \\
\text { prognostic factor in endometrial cancers } \\
\text { Clinicopathological features of programmed death }\end{array}$ & $\begin{array}{l}\text { Journal of Gynecologic } \\
\text { Oncology }\end{array}$ & Endometrial \\
\hline Kawazoe & 2017 & $\begin{array}{l}\text { ligand } 1 \text { expression with tumor-infiltrating lymphocyte, } \\
\text { mismatch repair, and Epstein-Barr virus status in a large } \\
\text { cohort of gastric cancer patients }\end{array}$ & Gastric Cancer & Gastric \\
\hline Kobel & 2017 & $\begin{array}{c}\text { Frequent mismatch repair protein deficiency in mixed } \\
\text { endometrioid and clear cell carcinoma of the } \\
\text { endometrium }\end{array}$ & $\begin{array}{l}\text { International Journal of } \\
\text { Gynecological Pathology }\end{array}$ & Endometrial \\
\hline
\end{tabular}


TABle 3: Continued.

\begin{tabular}{|c|c|c|c|c|}
\hline Author & Year & Title & Journal & Tumor type \\
\hline Liau & 2014 & $\begin{array}{l}\text { Hypermethylation of the cdkn2a gene promoter is a } \\
\text { frequent epigenetic change in periocular sebaceous } \\
\text { carcinoma and is associated with younger patient age }\end{array}$ & Human Pathology & Sebaceous \\
\hline Liu & 2014 & $\begin{array}{c}\text { DNA mismatch repair abnormalities in acinar cell } \\
\text { carcinoma of the pancreas frequency and clinical } \\
\text { significance }\end{array}$ & Pancreas & Pancreatic \\
\hline Milione & 2016 & $\begin{array}{c}\text { The clinicopathologic heterogeneity of grade } 3 \\
\text { gastroenteropancreatic neuroendocrine neoplasms: } \\
\text { morphological differentiation and proliferation identify } \\
\text { different prognostic categories }\end{array}$ & Neuroendocrinology & Gastroenteropancreatic \\
\hline Moreira & 2012 & $\begin{array}{l}\text { Identification of Lynch syndrome among patients with } \\
\text { colorectal cancer }\end{array}$ & JAMA & Colorectal \\
\hline Okoye & 2016 & $\begin{array}{c}\text { Defective DNA mismatch repair influences expression } \\
\text { of endometrial carcinoma biomarkers }\end{array}$ & $\begin{array}{l}\text { International Journal of } \\
\text { Gynecological Pathology }\end{array}$ & Endometrial \\
\hline Park & 2016 & $\begin{array}{l}\text { Epstein-Barr virus positivity, not mismatch repair- } \\
\text { deficiency, is a favorable risk factor for lymph node } \\
\text { metastasis in submucosa-invasive early gastric cancer }\end{array}$ & Gastric Cancer & Gastric \\
\hline Pecorino & 2017 & $\begin{array}{c}\text { Genetic screening in young women diagnosed with } \\
\text { endometrial cancer }\end{array}$ & $\begin{array}{l}\text { Journal of Gynecologic } \\
\text { Oncology }\end{array}$ & Endometrial \\
\hline Peterson & 2012 & $\begin{array}{c}\text { Molecular characterization of endometrial cancer: a } \\
\text { correlative study assessing microsatellite instability, } \\
\text { mlh1 hypermethylation, DNA mismatch repair protein } \\
\text { expression, and pten, pik3ca, kras, and braf mutation } \\
\text { analysis }\end{array}$ & $\begin{array}{l}\text { International Journal of } \\
\text { Gynecological Pathology }\end{array}$ & Endometrial \\
\hline Ramos & 2017 & $\begin{array}{l}\text { Lymphoepithelioma-like gastric carcinoma: } \\
\text { Clinicopathological characteristics and infection status }\end{array}$ & Journal of surgical Research & Gastric \\
\hline Ring & 2013 & $\begin{array}{l}\text { Women } 50 \text { years or younger with endometrial cancer the } \\
\text { argument for universal mismatch repair screening and } \\
\text { potential for targeted therapeutics }\end{array}$ & $\begin{array}{l}\text { International Journal of } \\
\text { Gynecological Cancer }\end{array}$ & Endometrial \\
\hline Roberts & 2013 & $\begin{array}{l}\text { Screening for Muir-Torre syndrome using mismatch } \\
\text { repair protein immunohistochemistry of sebaceous } \\
\text { neoplasms }\end{array}$ & Journal of Genetic Counseling & Sebaceous \\
\hline Rosa-Rosa & 2016 & $\begin{array}{c}\text { Molecular genetic heterogeneity in undifferentiated } \\
\text { endometrial carcinomas }\end{array}$ & Modern Pathology & Endometrial \\
\hline Ruiz & 2014 & $\begin{array}{l}\text { Lack of association between deficient mismatch repair } \\
\text { expression and outcome in endometrial carcinomas of } \\
\text { the endometrioid type }\end{array}$ & Gynecologic Oncology & Endometrial \\
\hline Sahnane & 2015 & $\begin{array}{l}\text { Microsatellite unstable gastrointestinal neuroendocrine } \\
\text { carcinomas: a new clinicopathologic entity }\end{array}$ & Endocrine-Related Cancer & Gastroenteropancreatic \\
\hline Shih & 2011 & $\begin{array}{c}\text { Clinicopathologic significance of DNA mismatch repair } \\
\text { protein defects and endometrial cancer in women } 40 \\
\text { years of age and younger }\end{array}$ & Gynecologic Oncology & Endometrial \\
\hline Steinestel & 2014 & $\begin{array}{c}\text { Invasion pattern and histologic features of tumor } \\
\text { aggressiveness correlate with MMR protein expression, } \\
\text { but are independent of activating kras and braf } \\
\text { mutations in CRC }\end{array}$ & Virchows Archiv & Colorectal \\
\hline Talhouk & 2016 & $\begin{array}{c}\text { Molecular classification of endometrial carcinoma on } \\
\text { diagnostic specimens is highly concordant with final } \\
\text { hysterectomy: earlier prognostic information to guide } \\
\text { treatment }\end{array}$ & Gynecologic Oncology & Endometrial \\
\hline Talhouk & 2015 & $\begin{array}{c}\text { A clinically applicable molecular-based classification for } \\
\text { endometrial cancers }\end{array}$ & British Journal of Cancer & Endometrial \\
\hline Talhouk & 2017 & $\begin{array}{l}\text { Confirmation of ProMisE: a simple, genomics-based } \\
\text { clinical classifier for endometrial cancer }\end{array}$ & Cancer & Endometrial \\
\hline Therkildsen & 2015 & $\begin{array}{l}\text { Glioblastomas, astrocytomas and oligodendrogliomas } \\
\text { linked to Lynch syndrome }\end{array}$ & European Journal of Neurology & Brain \\
\hline
\end{tabular}


TABle 3: Continued.

\begin{tabular}{|c|c|c|c|c|}
\hline Author & Year & Title & Journal & Tumor type \\
\hline Thoury & 2014 & $\begin{array}{l}\text { Evidence for different expression profiles for c-Met, } \\
\text { EGFR, PTEN and the mTOR pathway in low and high } \\
\text { grade endometrial carcinomas in a cohort of consecutive } \\
\text { women. Occurrence of pik } 3 \text { ca and k-ras mutations and } \\
\text { microsatellite instability }\end{array}$ & Histology and Histopathology & Endometrial \\
\hline Vierkoetter & 2014 & $\begin{array}{l}\text { Lynch syndrome in patients with clear cell and } \\
\text { endometrioid cancers of the ovary }\end{array}$ & Gynecologic Oncology & Ovarian \\
\hline Vierkoetter & 2016 & $\begin{array}{l}\text { Loss of mismatch repair protein expression in unselected } \\
\text { endometrial adenocarcinoma precursor lesions }\end{array}$ & $\begin{array}{l}\text { International Journal of } \\
\text { Gynecological Cancer }\end{array}$ & Endometrial \\
\hline Watkins & 2016 & $\begin{array}{l}\text { Universal screening for mismatch-repair deficiency in } \\
\text { endometrial cancers to identify patients with Lynch } \\
\text { syndrome and Lynch-like syndrome }\end{array}$ & $\begin{array}{l}\text { International Journal of } \\
\text { Gynecological Pathology }\end{array}$ & Endometrial \\
\hline Wiegand & 2014 & $\begin{array}{l}\text { Arid1a/baf250a as a prognostic marker for gastric } \\
\text { carcinoma: a study of } 2 \text { cohorts }\end{array}$ & Human Pathology & Gastric \\
\hline Woo & 2014 & $\begin{array}{l}\text { The immunohistochemistry signature of mismatch } \\
\text { repair (MMR) proteins in a multiethnic Asian cohort } \\
\text { with endometrial carcinoma }\end{array}$ & $\begin{array}{l}\text { International Journal of } \\
\text { Gynecological Pathology }\end{array}$ & Endometrial \\
\hline Zakhour & 2017 & $\begin{array}{l}\text { Abnormal mismatch repair and other clinicopathologic } \\
\text { predictors of poor response to progestin treatment in } \\
\text { young women with endometrial complex atypical } \\
\text { hyperplasia and well-differentiated endometrial } \\
\text { adenocarcinoma: a consecutive case series }\end{array}$ & $\begin{array}{l}\text { BJOG: An International Journal } \\
\text { of Obstetrics and Gynecology }\end{array}$ & Endometrial \\
\hline
\end{tabular}

TABLE 4: References-genomic studies.

\begin{tabular}{|c|c|c|c|c|}
\hline Author & Year & Title & Journal & Tumor type \\
\hline Bonneville & 2017 & Landscape of microsatellite instability across 39 cancer types & $\begin{array}{l}\text { JCO Precision } \\
\text { Oncology }\end{array}$ & $\begin{array}{c}\text { Many } \\
\text { (genomic) }\end{array}$ \\
\hline Chalmers & 2017 & $\begin{array}{l}\text { Analysis of 100,000 human cancer genomes reveals the landscape of tumor } \\
\text { mutational burden }\end{array}$ & Genome Medicine & $\begin{array}{l}\text { Many } \\
\text { (genomic) }\end{array}$ \\
\hline $\begin{array}{l}\text { Cortes- } \\
\text { Ciriano }\end{array}$ & 2017 & A molecular portrait of microsatellite instability across multiple cancers & $\begin{array}{l}\text { Nature } \\
\text { Communications }\end{array}$ & $\begin{array}{c}\text { Many } \\
\text { (genomic) }\end{array}$ \\
\hline Hause & 2016 & $\begin{array}{c}\text { Classification and characterization of microsatellite instability across } 18 \\
\text { cancer types }\end{array}$ & Nature Medicine & $\begin{array}{l}\text { Many } \\
\text { (genomic) }\end{array}$ \\
\hline Le & 2017 & $\begin{array}{c}\text { Mismatch-repair deficiency predicts response of solid tumors to PD-1 } \\
\text { blockade }\end{array}$ & Science & $\begin{array}{l}\text { Many } \\
\text { (genomic) }\end{array}$ \\
\hline
\end{tabular}

TABLe 5: Availability of prevalence data.

\begin{tabular}{|c|c|c|c|c|c|c|}
\hline Subset & $\begin{array}{c}\text { Any (with and } \\
\text { without results) }\end{array}$ & $\begin{array}{c}\text { Reported MSI- } \\
\text { H data }\end{array}$ & $\begin{array}{c}\text { Reported dMMR } \\
\text { (any IHC) }\end{array}$ & $\begin{array}{l}\text { Reported dMMR ( } 4 \\
\text { MMR proteins) }\end{array}$ & $\begin{array}{l}\text { Reported } \\
\text { MSS }\end{array}$ & $\begin{array}{c}\text { Reported MSI- } \\
\text { H/dMMR }\end{array}$ \\
\hline $\begin{array}{l}\text { Total number of } \\
\text { studies included }\end{array}$ & 156 & 94 & 66 & 54 & 79 & 140 \\
\hline $\begin{array}{l}\text { Studies in gastric } \\
\text { cancer }\end{array}$ & 39 & 32 & 6 & 4 & 23 & 35 \\
\hline $\begin{array}{l}\text { Studies in endometrial } \\
\text { cancer }\end{array}$ & 53 & 27 & 28 & 26 & 16 & 49 \\
\hline $\begin{array}{l}\text { Studies in ovarian } \\
\text { cancer }\end{array}$ & 23 & 17 & 8 & 5 & 13 & 20 \\
\hline $\begin{array}{l}\text { Studies in colorectal } \\
\text { cancer }\end{array}$ & 20 & 14 & 8 & 4 & 6 & 17 \\
\hline $\begin{array}{l}\text { Studies in esophageal } \\
\text { cancer }\end{array}$ & 6 & 6 & 0 & 0 & 3 & 6 \\
\hline Studies in renal cancer & 9 & 7 & 3 & 1 & 3 & 8 \\
\hline $\begin{array}{l}\text { Studies in other } \\
\text { cancers }\end{array}$ & 36 & 18 & 16 & 13 & 21 & 31 \\
\hline
\end{tabular}

Abbreviations: MSI-H, microsatellite instability-high; dMMR, deficient mismatch repair; MSS, microsatellite stable. 


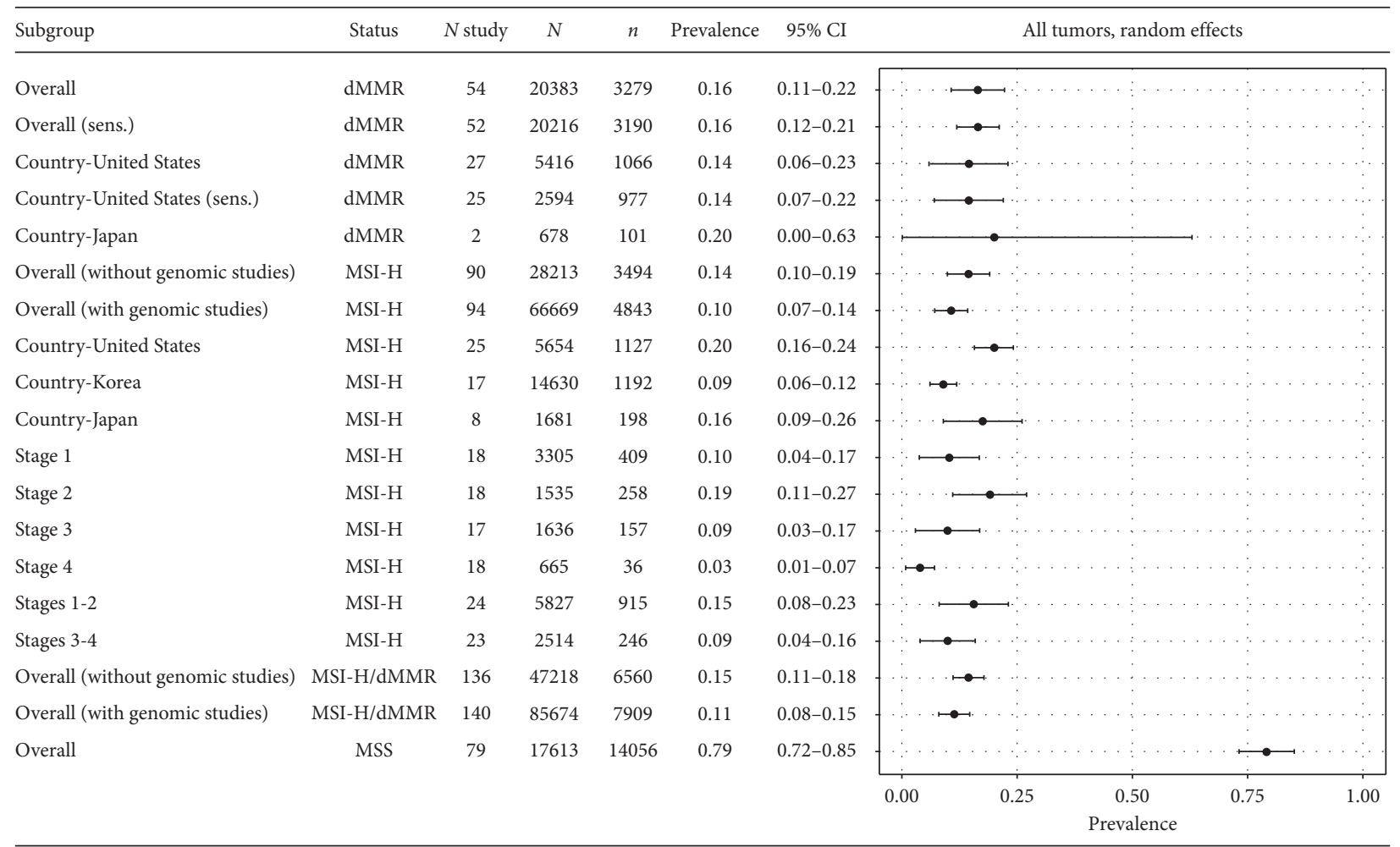

FIGURE 2: Summary of meta-analysis results, all tumor types, random effects. Abbreviations: $N$, total number of subjects; $n$, number of subjects with mutation status of interest.

tumor types and stages. This estimate remained unchanged $(16 \%(95 \% \mathrm{CI}, 12 \%-21 \%))$ in the sensitivity analysis, in which two studies (Everett 2014 and Roberts 2013) that possibly screened patients based on their Lynch syndrome status were excluded. Overall, MSS prevalence was found to be $79 \%$ (95\% CI, 72\%-85\%) across tumor types and stages. Estimated pooled MSI-H and dMMR prevalence without genomic studies was 15\% (95\% CI, 11\%-18\%) and dropped to $11 \%(95 \% \mathrm{CI}, 8 \%-15 \%)$ when genomic studies were included.

Country-specific MSI-H prevalence was estimated only in the United States, Korea, and Japan, for which at least 2 publications were included. The weighted prevalence of MSI-H for the United States, Korea, and Japan was estimated at $20 \%(95 \% \mathrm{CI}, 16 \%-24 \%), 9 \%(95 \% \mathrm{CI}, 6 \%-12 \%)$, and $16 \%$ (95\% CI, 9\%-26\%), respectively, across all cancers and stages. dMMR all-stage prevalence for the United States was estimated at $14 \%(95 \% \mathrm{CI}, 6 \%-23 \%)$ and for Japan was estimated at $20 \%(95 \% \mathrm{CI}, 0 \%-63 \%)$. Stages $1-2 \mathrm{MSI}-\mathrm{H}$ prevalence was $15 \%(8-23 \%)$, while stage 3 and stage 4 prevalence was estimated at $9 \%(3 \%-17 \%)$ and $3 \%(1 \%-7 \%)$, respectively.

Tumor-specific meta-analysis was feasible for 3 key gastrointestinal tumors (gastric, colorectal, and esophageal), 2 gynecological tumors (endometrial and ovarian), and 1 genitourinary tumor (renal) with results presented in Figures 3-5. Among the gastrointestinal tumors, gastric cancer MSI-H pooled prevalence (with 95\% CI) from 32 studies (16,308 patients) was estimated at $11 \%(9-12 \%)$ and dMMR pooled prevalence from 4 studies (854 patients) was estimated at $8 \%(2-17 \%)$; Based on stages across gastrointestinal tumors, the prevalence was $13 \%(10 \%-16 \% ; 10$ studies; 3,194 patients) for stages $1-2$, and the prevalence was $10 \%$ (7-13\%; 10 studies; 1,319 patients) in stages 3-4 cancer. The highest MSI-H pooled prevalence was observed for the intestinal histological subtype with $13 \%(10-17 \%)$ based on 14 studies (2,652 patients). In CRC, MSI-H pooled prevalence from 14 studies (8,156 patients) was estimated at $13 \%$ $(10-16 \%)$ and dMMR pooled prevalence from 4 studies $(11,434$ patients) was estimated at $10 \%(5-15 \%)$. For stages 1-2 CRC, the prevalence was $20 \%(10 \%-32 \%$; 4 studies; 888 patients), and for stages $3-4$, the prevalence was $9 \%$ (3-16\%; 4 studies; 873 patients). Based on histology, the highest MSI$\mathrm{H}$ pooled prevalence was observed for the poorly differentiated CRC subtype with 32\% (25-40\%) based on 6 studies (1,204 patients). Among esophageal cancers, MSI-H pooled prevalence from 3 studies (147 patients) was estimated at $4 \%$ (0-11\%). For stages 3-4 esophageal cancers, the prevalence was $18 \%$ (4\%-39\%; 2 studies; 62 patients). Based on histology, the highest MSI-H pooled prevalence was observed for well-differentiated and poorly differentiated esophageal subtypes with $16 \%(3-35 \%)$ and $16 \%(0 \%-45 \%)$, respectively. dMMR analysis was not feasible for esophageal tumors. For the gynecological tumors, endometrial cancer MSI-H pooled prevalence from 27 studies (6,813 patents) was estimated at $26 \%(23-29 \%)$ and dMMR pooled prevalence from 26 studies (5,248 patients) was estimated at $25 \%$ (22-28\%). In ovarian cancers, MSI-H pooled prevalence from 17 studies (4,150 patients) was estimated at $11 \%$ (6-18\%) and dMMR pooled prevalence from 5 studies (356 


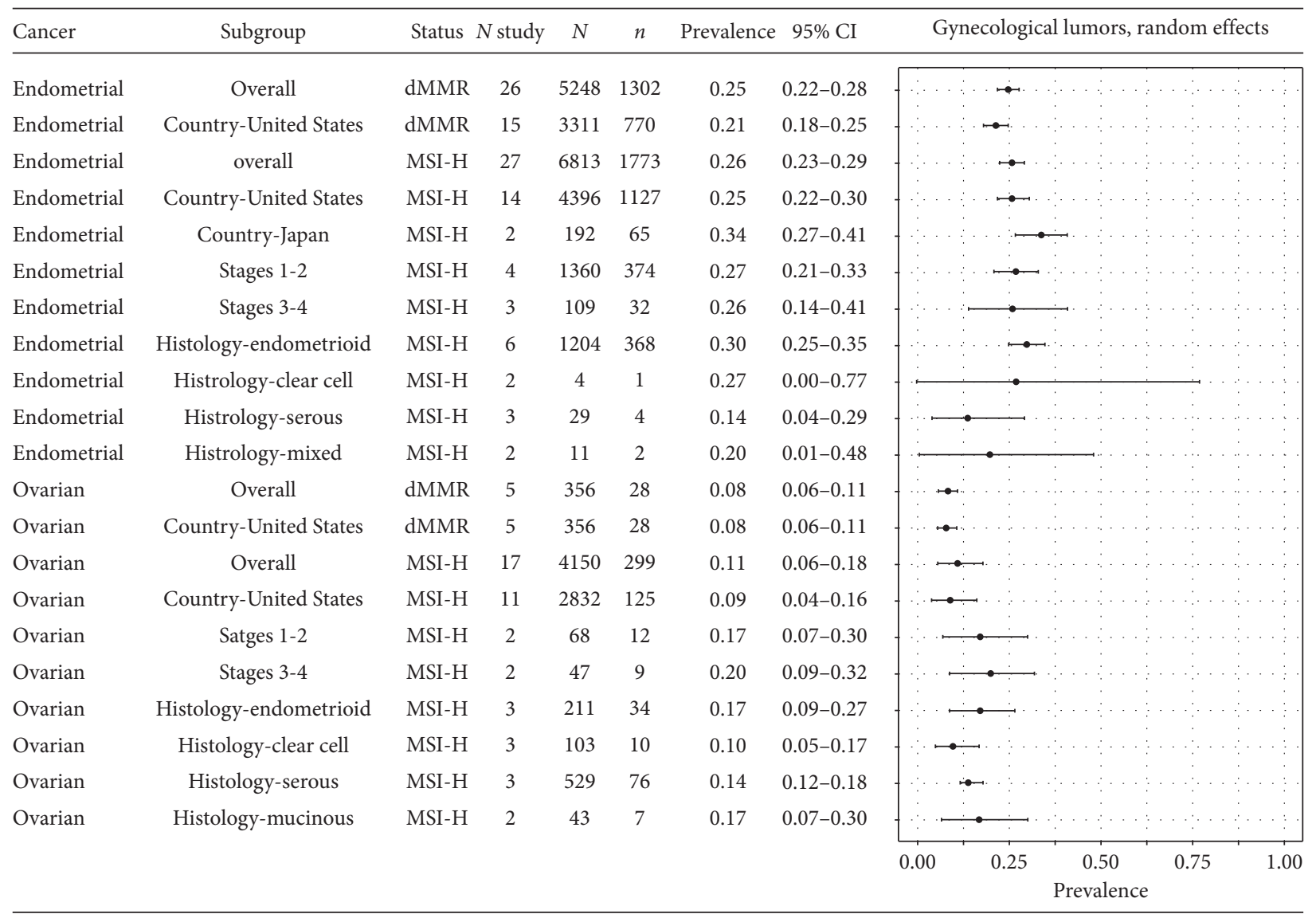

FiguRE 3: Summary of meta-analysis results, gynecological tumors, random effects. Abbreviations: $N$, total number of subjects; $n$, number of subjects with mutation status of interest.

patients) was estimated at $8 \%(6-11 \%)$. Based on histology, the highest MSI-H pooled prevalence was observed for endometrioid subtype for each tumor with 30\% (25-35\%) based on 6 studies (1,204 patients) for endometrial cancers and $17 \%(25-35 \%)$ based on 3 studies (211 patients) for ovarian cancers. Among renal tumors, MSI-H all-stage prevalence was estimated to be $1 \%(95 \%$ CI, $0 \%-2 \%)$ based on 7 studies (2,231 patients); dMMR analysis was not feasible for renal tumors.

\section{Discussion}

This structured literature review and meta-analysis investigated MSI-H and dMMR prevalence across tumor types and compared prevalence estimates by tumor type, tumor stage, and country subgroups. Analysis results estimated the prevalence of MSI-H across all tumor types as $14 \%$ (95\% CI, $10 \%-19 \%)$. dMMR prevalence was comparable at 16\% (95\% CI, $11 \%-22 \%)$.

Pooled dMMR prevalence estimates by tumor type were similar to those for MSI-H. It has been suggested that, for Lynch syndrome testing, PCR testing may be less sensitive than IHC due to the fact that mutations in MSH6 may present as MSI-L [23]. The results of this review, however, suggest that MSI-H and dMMR IHC testing results are generally comparable.
The United States had higher MSI-H prevalence than Korea and Japan, but this result is possibly biased due to the lack of weighting for country-specific tumor prevalence.

Subgroup analysis indicated that early stage diseases (stage 1 and 2) tended to have a higher MSI-H prevalence than later stages (stages 3 and 4). Numerous studies have established the value of MSI status as a prognostic factor [24-26]. Results of a meta-analysis including 7642 patients indicated that MSI (MSI-H + MSI-L) tumors corresponded with significantly improved prognosis compared to MSS CRCs (overall survival HR 0.65 (95\% CI, 0.59-0.71) [27]. This may partially explain the lower MSI-H prevalence in the later stages of cancers.

Some tumor types had noticeably higher MSI-H prevalence than others. Endometrial tumors had MSI-H prevalence of $26 \%$ (95\% CI, 23\%-29\%), whereas renal tumors only had MSI-H prevalence of $1 \%(95 \%$ CI, $0 \%-2 \%)$. This observation corroborates findings from recent genomic studies, which revealed that the frequency of MSI-H events is highly variable across tumor types $[13,28]$. One study noted that MSI-H prevalence was highest in Lynch syndromeassociated tumor types (endometrial, colon, gastric, and rectal) [13] which is well-aligned with findings from the current study.

The identified evidence base included 156 articles reporting on the prevalence of MSI-H and/or dMMR 


\begin{tabular}{|c|c|c|c|c|c|c|c|c|}
\hline Cancer & Subgroup & Status & $N$ study & $N$ & $n$ & Prevalence & $95 \% \mathrm{CI}$ & Gastrointestinal lumors, random effects \\
\hline Gastric & Overall & $\mathrm{dMMR}$ & 4 & 854 & 72 & 0.08 & $0.02-0.17$ & $\therefore \quad \vdots$ \\
\hline Gastric & Overall & MSI-H & 32 & 16308 & 1441 & 0.11 & $0.09-0.12$ & $\cdot:$ \\
\hline Gastric & Country-United States & MSI-H & 4 & 993 & 168 & 0.16 & $0.11-0.22$ & \\
\hline Gastric & Country-Korea & MSI-H & 14 & 13122 & 1015 & 0.08 & $0.07-0.10$ & $\therefore$ \\
\hline Gastric & Stages 1-2 & MSI-H & 10 & 3194 & 346 & 0.13 & $0.10-0.16$ & $\rightarrow$ \\
\hline Gastric & Stages 3-4 & MSI-H & 10 & 1319 & 104 & 0.10 & $0.07-0.13$ & $\therefore \rightarrow$ \\
\hline Gastric & Histology-intestinal & MSI-H & 14 & 2652 & 348 & 0.13 & $0.10-0.17$ & \\
\hline Gastric & Histology-diffuse & MSI-H & 14 & 2281 & 104 & 0.05 & $0.03-0.08$ & -1 \\
\hline Gastric & Histology-mixed & MSI-H & 8 & 368 & 35 & 0.10 & $0.07-0.13$ & $\because$ \\
\hline Colorectal & Overall & dMMR & 4 & 11434 & 1513 & 0.10 & $0.05-0.15$ & \\
\hline Colorectal & Overall & MSI-H & 14 & 8156 & 937 & 0.13 & $0.10-0.16$ & \\
\hline Colorectal & Country-United States & MSI-H & 5 & 4820 & 569 & 0.12 & $0.08-0.17$ & \\
\hline Colorectal & Country-Korea & MSI-H & 4 & 1530 & 182 & 0.13 & $0.05-0.24$ & $?$ \\
\hline Colorectal & Stages 1-2 & MSI-H & 4 & 888 & 144 & 0.20 & $0.10-0.32$ & \\
\hline Colorectal & Stages 3-4 & MSI-H & 4 & 873 & 69 & 0.09 & $0.03-0.16$ & $\cdots$ \\
\hline Colorectal & Histology-well-differentiated & MSI-H & 2 & 149 & 12 & 0.08 & $0.04-0.13$ & $\rightarrow$ \\
\hline Colorectal & Histology-poorly differentiated & MSI-H & 3 & 147 & 47 & 0.32 & $0.25-0.40$ & \\
\hline Colorectal & Histology-mucinous & MSI-H & 2 & 21 & 3 & 0.14 & $0.00-0.36$ & $\therefore$ \\
\hline Esophageal & Overall & MSI-H & 6 & 731 & 33 & 0.04 & $0.00-0.11$ & 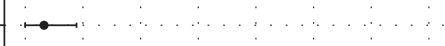 \\
\hline Esophageal & Country-United States & MSI-H & 2 & 383 & 4 & 0.01 & $0.00-0.02$ & $\therefore$ \\
\hline Esophageal & Country-Japan & MSI-H & 2 & 138 & 26 & 0.15 & $0.01-0.39$ & \\
\hline Esophageal & Stages 3-4 & MSI-H & 2 & 62 & 13 & 0.18 & $0.04-0.93$ & i. \\
\hline Esophageal & Histology-well-differentiated & MSI-H & 3 & 46 & 7 & 0.16 & $0.03-0.35$ & 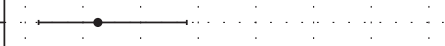 \\
\hline Esophageal & Histology-moderately differentiate & MSI-H & 3 & 65 & 9 & 0.09 & $0.00-0.27$ & $\longrightarrow$ \\
\hline \multirow[t]{2}{*}{ Esophageal } & Histology-poorly differentiated & MSI-H & 3 & 50 & 10 & 0.16 & $0.00-0.45$ & $\therefore$ \\
\hline & & & & & & & & $\begin{array}{llcc}0.00 & 0.25 & \begin{array}{c}0.50 \\
\text { Prevalence }\end{array} & 0.75\end{array}$ \\
\hline
\end{tabular}

FIGURE 4: Summary of meta-analysis results, gastrointestinal tumors, random effects. Abbreviations: $N$, total number of subjects; $n$, number of subjects with mutation status of interest.

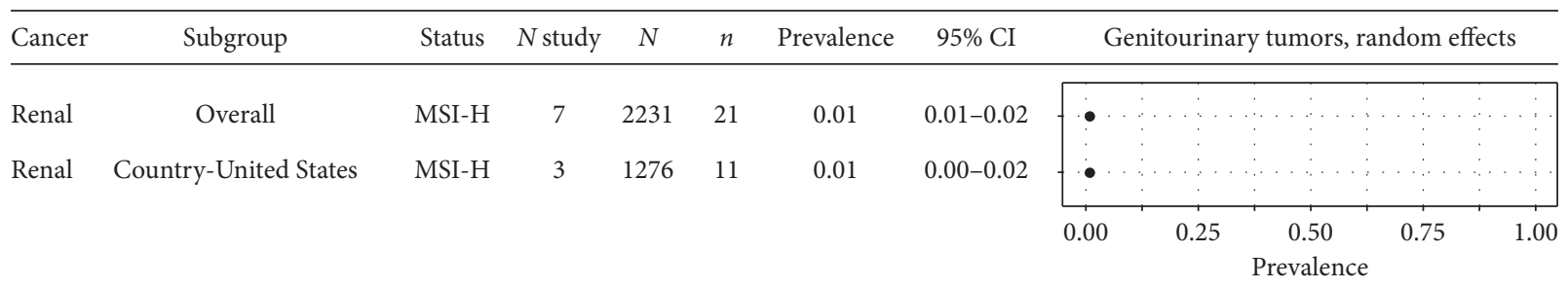

FIGURE 5: Summary of meta-analysis results, genitourinary tumors, random effects. Abbreviations: $N$, total number of subjects; $n$, number of subjects with mutation status of interest.

published between 1999 and 2017. This review includes the most cancer types of a published review to date. Of the other two known published meta-analyses that have quantified the prevalence of MSI-H for selective tumors, the first (including publications to 2007) reported an MSI-H prevalence of $12 \%$ (95\% CI, 8\%-17\%) in ovarian tumors [29], the second (including publications to 2009) reported an MSI-H prevalence of $10 \%(95 \% \mathrm{CI}, 6 \%-14 \%)$ in ovarian tumors [30], and the third (including studies published up to 2014) reported an MSI-H prevalence of $17 \%$ (95\% CI, 15\%-19\%) in colorectal tumors [31]. The finding from the current metaanalysis suggests MSI-H prevalence of 11\% (95\% CI, 6\%$18 \%)$ in ovarian cancer patients and $13 \%$ (95\% CI, $10 \%-$ $16 \%)$ in colorectal cancer patients, which are well-aligned with findings from previous meta-analyses.

This large-scale meta-analysis of the prevalence of MSI$\mathrm{H}$ and $\mathrm{dMMR}$ used rigorous methodology in selection of testing methods, subgroup analyses, and incorporation of pan-tumor genomic studies in sensitivity analyses. First, this meta-analysis of MSI-H and dMMR prevalence included the 
most number of studies (156) to date. Second, weighting techniques were used to adjust for overall tumor prevalence in order to prevent oversampling of commonly reported tumor types. Third, only studies that utilized the "gold standard" MSI-H and dMMR testing methods were included in the meta-analysis, so the results from these studies were more comparable. Fourth, the subgroup analyses, which were stratified by factors such as tumor type, country, and disease stage, indicated which factors had potential association with prevalence. Fifth, the inclusion of pan-tumor genomic studies in the sensitivity analyses offered an alternative scenario and suggested that the testing method used in large-scale genomic studies (sequencing) is significantly different from the widely accepted methods (PCR and IHC) used in other included studies.

This meta-analysis has some limitations. First, the literature review for CRC was a targeted hand search; some potentially relevant publications may not have been identified. Studies were reviewed by a single researcher, but a quality check was performed to validate the dataset. An additional limitation was the heterogeneity of included study designs included, which included case control, cross-sectional, prospective cohort, and retrospective cohort studies. However, because of scarcity of the numbers in most cancer types, studies with different designs were included to maximize the data sources. Symmetry was observed on most funnel plots, which suggest a lack of publication bias. To address heterogeneity in study designs included in the meta-analysis, data were analyzed using fixed- and random-effects models; however, this exploration did not provide evidence of any specific source of heterogeneity. Finally, given the lack of MSI/ MMR publications on a few major cancer types, the "overall" prevalence estimate does not include all solid tumors.

Recent evidence $[32,33]$ supporting the role of MSI-H and $\mathrm{dMMR}$, and associated immunogenicity as a mechanism for increased efficacy of PD-1/PD-L1 blockade in metastatic tumors with MSI-H or dMMR [8], demonstrates to the importance of increasing understanding [34] of prevalence across tumor type, stage, histology, and ethnicity.

\section{Conflicts of Interest}

M. Amonkar and K.-L. Liaw are employees of and own shares in Merck \& Co, Inc. The other authors declare no conflicts of interests.

\section{Acknowledgments}

This work was financially supported by Merck Sharp \& Dohme Corp., a subsidiary of Merck \& Co., Inc., Kenilworth, NJ, USA.

\section{Supplementary Materials}

Meta-analysis results obtained from random effects model in all tumor types are presented as forest plots in the Supplementary information (Appendix Figures 1-Figure 26). Funnel plots obtained from each meta-analysis are also presented in the Supplementary information (Appendix Figure 27-Figure 44). (Supplementary Materials)

\section{References}

[1] K. D. Berg, C. L. Glaser, R. E. Thompson, S. R. Hamilton, C. A. Griffin, and J. R. Eshleman, "Detection of microsatellite instability by fluorescence multiplex polymerase chain reaction," The Journal of Molecular Diagnostics, vol. 2, no. 1, pp. 20-28, 2000.

[2] P. Ward, L. Dubeau, C. Felix J, G. Kim, and J. Bacher, "Comparison between performance of primers for long versus short microsatellite biomarkers in the detection of microsatellite instability due to aberrant MSH6 expression in endometrioid carcinomas," in Proceedings of the Association for Molecular Pathology, Bethesda, MD, USA, November 2014.

[3] C. R. Boland, S. N. Thibodeau, S. R. Hamilton et al., "A National Cancer Institute workshop on microsatellite instability for cancer detection and familial predisposition: development of international criteria for the determination of microsatellite instability in colorectal cancer," Cancer Research, vol. 58, no. 22, pp. 5248-5257, 1998.

[4] A. Umar, C. R. Boland, J. P. Terdiman et al., "Revised Bethesda guidelines for hereditary nonpolyposis colorectal cancer (lynch syndrome) and microsatellite instability," JNCI Journal of the National Cancer Institute, vol. 96, no. 4, pp. 261-268, 2004.

[5] W. K. Funkhouser Jr., I. M. Lubin, F. A. Monzon et al., "Relevance, pathogenesis, and testing algorithm for mismatch repair-defective colorectal carcinomas," The Journal of Molecular Diagnostics, vol. 14, no. 2, pp. 91-103, 2012.

[6] S. Venderbosch, I. D. Nagtegaal, T. S. Maughan et al., "Mismatch repair status and BRAF mutation status in metastatic colorectal cancer patients: a pooled analysis of the CAIRO, CAIRO2, COIN, and FOCUS studies," Clinical Cancer Research, vol. 20, no. 20, pp. 5322-5330, 2014.

[7] P. P. Singh, P. K. Sharma, G. Krishnan, and A. C. Lockhart, "Immune checkpoints and immunotherapy for colorectal cancer," Gastroenterology Report, vol. 3, p. gov053, 2015.

[8] D. T. Le, J. N. Uram, H. Wang et al., "PD-1 blockade in tumors with mismatch-repair deficiency," New England Journal of Medicine, vol. 372, no. 26, pp. 2509-2520, 2015.

[9] J. C. Dudley, M.-T. Lin, D. T. Le, and J. R. Eshleman, "Microsatellite instability as a biomarker for PD-1 blockade," Clinical Cancer Research, vol. 22, no. 4, pp. 813-820, 2016.

[10] D. Moher, A. Liberati, J. Tetzlaff, D. G. Altman, and P. Group, "Preferred reporting items for systematic reviews and metaanalyses: the PRISMA statement," Journal of Clinical Epidemiology, vol. 62, no. 10, pp. 1006-1012, 2009.

[11] J. J. Miller, "The inverse of the freeman-Tukey double arcsine transformation," The American Statistician, vol. 32, no. 4, p. 138, 1978.

[12] R. DerSimonian and N. Laird, "Meta-analysis in clinical trials," Controlled Clinical Trials, vol. 7, no. 3, pp. 177-188, 1986.

[13] R. Bonneville, M. A. Krook, E. A. Kautto et al., "Landscape of microsatellite instability across 39 cancer types," JCO Precision Oncology, no. 1, pp. 1-15, 2017.

[14] I. Danielsson and L. Lister, "A pilot study of the teratogenicity of vagus nerve stimulation in a rabbit model," Brain Stimulation, vol. 2, no. 1, pp. 41-49, 2009.

[15] NCI, SEER, https://seer.cancer.gov/statfacts/html/oralcav. html. 
[16] G. W. Jung, A. I. Metelitsa, D. C. Dover, and T. G. Salopek, "Trends in incidence of nonmelanoma skin cancers in Alberta, Canada, 1988-2007," The British Journal of Dermatology, vol. 163, no. 163, pp. 146-154, 2010.

[17] S. Y. Pan and H. Morrison, "Epidemiology of cancer of the small intestine," World Journal of Gastrointestinal Oncology, vol. 3, no. 3, pp. 33-42, 2011.

[18] AAO, http://eyewiki.aao.org/Retinoblastoma.

[19] I. Alldinger, K. L. Schaefer, D. Goedde et al., "Microsatellite instability in Ewing tumor is not associated with loss of mismatch repair protein expression," Journal of Cancer Research and Clinical Oncology, vol. 133, no. 10, pp. 749-759, 2007.

[20] A. M. Cesinaro, A. Ubiali, P. Sighinolfi, G. P. Trentini, F. Gentili, and F. Facchetti, "Mismatch repair proteins expression and microsatellite instability in skin lesions with sebaceous differentiation: a study in different clinical subgroups with and without extracutaneous cancer," The American Journal of Dermatopathology, vol. 29, no. 4, pp. 351-358, 2007.

[21] R. Kumagai, K. Kohashi, S. Takahashi et al., "Mucinous phenotype and CD10 expression of primary adenocarcinoma of the small intestine," World Journal of Gastroenterology, vol. 21, no. 9, pp. 2700-2710, 2015.

[22] Y.-F. Wong, T.-H. Cheung, K.-Y. Poon et al., "The role of microsatellite instability in cervical intraepithelial neoplasia and squamous cell carcinoma of the cervix," Gynecologic Oncology, vol. 89, no. 3, pp. 434-439, 2003.

[23] Y. Wu, M. J. W. Berends, R. G. J. Mensink et al., “Association of hereditary nonpolyposis colorectal cancer-related tumors displaying low microsatellite instability with MSH6 germline mutations," The American Journal of Human Genetics, vol. 65, no. 5, pp. 1291-1298, 1999.

[24] A. Copija, D. Waniczek, A. Witkos, K. Walkiewicz, and E. Nowakowska-Zajdel, "Clinical significance and prognostic relevance of microsatellite instability in sporadic colorectal cancer patients," International Journal of Molecular Sciences, vol. 18, no. 1, 2017.

[25] K. C. Halling, A. J. French, S. K. McDonnell et al., "Microsatellite instability and $8 \mathrm{p}$ allelic imbalance in stage B2 and C colorectal cancers," JNCI Journal of the National Cancer Institute, vol. 91, no. 15, pp. 1295-1303, 1999.

[26] S. A. Khan, M. Morris, K. Idrees et al., "Colorectal cancer in the very young: a comparative study of tumor markers, pathology and survival in early onset and adult onset patients," Journal of Pediatric Surgery, vol. 51, no. 11, pp. 1812-1817, 2016.

[27] S. Popat, R. Hubner, and R. S. Houlston, "Systematic review of microsatellite instability and colorectal cancer prognosis," Journal of Clinical Oncology, vol. 23, no. 3, pp. 609-618, 2005.

[28] I. Cortes-Ciriano, S. Lee, W. Y. Park, T. M. Kim, and P. J. Park, "A molecular portrait of microsatellite instability across multiple cancers," Nature Communications, vol. 8, p. 15180, 2017.

[29] T. Pal, J. Permuth-Wey, A. Kumar, and T. A. Sellers, "Systematic review and meta-analysis of ovarian cancers: estimation of microsatellite-high frequency and characterization of mismatch repair deficient tumor histology," Clinical Cancer Research, vol. 14, no. 21, pp. 6847-6854, 2008.

[30] M. A. Murphy and N. Wentzensen, "Frequency of mismatch repair deficiency in ovarian cancer: a systematic review this article is a US Government work and, as such, is in the public domain of the United States of America," International Journal of Cancer, vol. 129, no. 8, pp. 1914-1922, 2011.
[31] H. Ashktorab, S. Ahuja, L. Kannan et al., "A meta-analysis of MSI frequency and race in colorectal cancer," Oncotarget, vol. 7, no. 23, pp. 34546-34557, 2016.

[32] KEYTRUDA ${ }^{\circledR}$ (pembrolizumab, Highlights of Prescribing Information, Merck Sharp \& Dohme Corp, Kenilworth, NJ, USA, 2018.

[33] OPDIVO ${ }^{\circledR}$ (nivolumab), Highlights of Prescribing Information, Bristol-Myers Squibb Corp, New York, NY, USA, 2018.

[34] National Comprehensive Cancer Network, Clinical Practice Guidelines in Oncology, National Comprehensive Cancer Network, Fort Washington, PA, USA, 2019. 